\title{
干しえびのだし汁調製法における超音波照射の効果
}

加賀谷みえ子*・佐々木弘子**・藤原しのぶ**・菅原龍幸**

(*椙山女学園大学, **聖徳大学)

\section{Effects of ultrasonication on the preparation method for the soup stock of the dried shrimps}

\author{
Mieko Kagaya * , Hiroko Sasaki **, Sinobu Fujiwara **, Tatsuyuki Sugahara ** \\ * Sugiyama Jogakuen University, \\ 17- 3 , Hoshigaokamotomachi, Chikusa-ku, Nagoya-shi, Aichi, 464-8662 \\ ** Seitoku University, 550, Iwase, Matsudo-shi, Chiba, 271-8555 \\ *テ464-8662 愛知県名古屋市千種区星が丘元町17-3 \\ ***271-8555 千葉県松戸市岩瀬550
}

In order to find a quick and rational analysis method for the soup stock of Japanese dried shrimp, the effect of the irradiation time and frequency difference extraction by ultrasonic irradiation combined with immersion method conventional 1 -hour was examined. The resulting color L* was slightly low in the sample which underwent ultrasonic-treatment than without ultrasonic-treatment, and the b volume was high. The multi-frequency ultrasonication $(a, b, \Delta E)$ showed a high value from $200 \mathrm{kHz}$. For all the extracts, the amino nitrogen, IMP, AMP, and lactic acid compare the multi-frequency ultrasonication with $200 \mathrm{kHz}$ for the temperature rise $(p<0.01)$. For the IMP, it showed a high value for the extraction temperature $50^{\circ} \mathrm{C}$ and the multi-frequency ultrasonication for 10 minutes, and the free amino acids were high at $50^{\circ} \mathrm{C}$ and for the multi-frequency ultrasonication at 30 minutes.

In the ranking of the sensory evaluation, $25^{\circ} \mathrm{C}$ and the multi-frequency ultrasonication for 15 minutes, and $50{ }^{\circ} \mathrm{C}$ and the multi-frequency ultrasonication for 10 minutes was the best $(p<0.01)$. As for comparing these two samples, $50^{\circ} \mathrm{C}$ and the multi-frequency ultrasonication for 10 minutes obtained a significantly higher preference rating of color, full of bodies, umami, and overall likeability $(p<0.001)$. The desirable preparation conditions of the shrimp broth extraction was $50{ }^{\circ} \mathrm{C}$ and the multi-frequency ultrasonication for 10 minutes.

1. 緒言

干しえびは保存が利き，中国料理の素材として利用さ れることが多い貴重な食材で, 水戻しして利用されるこ とが多く ${ }^{1)}$ ，スープストックとしての利用価值が高い。 一般に中国料理に用いられる干しえびは，中国産のも のが多い。えびの呈味成分はグリシン，アラニンおよび グルタミン酸を主体とするアミノ酸類であること到, また旨味成分として AMP, IMP および CMPが関与し

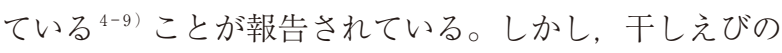
だし汁の合理的な抽出法に関する研究は未だ見当たらな
い。すでに著者らは，たし汁の調製において抽出過程中 に超音波照射を併用することで, 食品の旨味溶出成分が 増加することを干ししいたけ，昆布，䳕骨などの食材で 報告している ${ }^{10-13)}$ 。超音波洗浄では, 液体中に超音波を 照射すると，物理的作用によって減圧と加圧が交互に発 生し, キャビテーションが起こる。そのため液体は超音 波によって振動し, その加速度による力や直進流が発生 して，表面の污れなどを剥ぎ取る作用により洗浄効果が 認められている。

本研究では，干しえびのだし汁の抽出においても超音 波照射の効果が期待できると考え，日本産干しえびのだ 
し汁の簡便・迅速かつ合理的で，嗜好性の優れた条件を 見出すことを目的に, 従来型と新開発型の 2 種類の超音 波装置を用い，超音波照射併用の有無や超音波照射時間 の相違と抽出効果などのモデル実験を試み，超音波照射 条件の検討とだし汁中の呈味成分，色調㧍よび嗜好との 関係を明らかにするとともに干しえびのだし汁の好適な 調製条件について検討した。

\section{2. 実験方法}

\section{（1）試＼cjkstart料}

試料は, 日本産 (2009年徳島・瀬戸内近海産)の干しえ びを使用した。干しえびの形状を表 1 に示した。試料は モリタケ八百秀で購入し， $-30^{\circ} \mathrm{C}$ で冷凍保存し，実験に 使用する際は室温に戻して用いた。

\section{（2）試料溶液の調製}

浸水法の過程で用いる超音波発振装置の照射条件を選 定するために，従来型の本多電子（株）製 W-113型 $(28 \mathrm{kHz} 5$ 秒間, $45 \mathrm{kHz} 5$ 秒間, $100 \mathrm{kHz} 1$ 秒間のマル 千周波併用発振，以下マルチ周波と略す）と同製の新開 発型（200kHz一定発振，以下 $200 \mathrm{kHz}$ と略す）の超音波 発振装置を用いて分析試料の調製を行った。試料調製条 件は表 2 に示した。

前処理として，干しえび $6 \mathrm{~g}$ を秤量し $500 \mathrm{~mL}$ 容ビー カーに入れ， $50^{\circ} \mathrm{C}$ の蒸留水 $300 \mathrm{~mL}$ で 1 分間浸漬後濾過

\section{表 1 干しえびの形状}

\begin{tabular}{ccccc}
\hline 産地 & $\begin{array}{c}\text { 長さ } \\
(\mathrm{cm})\end{array}$ & $\begin{array}{c}\text { 厚さ } \\
(\mathrm{cm})\end{array}$ & $\begin{array}{c}\text { 重量 } \\
(\mathrm{g})\end{array}$ & $\begin{array}{c}\text { 水分含量 } \\
(\%)\end{array}$ \\
\hline 日本産 & $1.62 \pm 0.08$ & $0.55 \pm 0.02$ & $0.83 \pm 0.10$ & 21.6 \\
\hline 参考：日本食品標準成分表2010に扔ける干しえびの水分含量は $24.2 \%$, \\
$n=10$
\end{tabular}

した。だし汁の作成は，既報9)の方法を参考に，以下の 手順で行った。前処理後の干しえびを $500 \mathrm{~mL}$ 容トール ビーカーに入れ， $10 ， 25$ ，打上び $50^{\circ} \mathrm{C}$ の蒸留水を加え $300 \mathrm{~g}$ とし，2％（w/v）の濃度に調製した。ビーカーに アルミホイルで蓋をし，10，25，および50Cの条件下で30 分間浸漬を行い, その後に超音波照射 (以後, 照射と略す) を10，15，㧍よび30分間行った。10，15分間照射の試料は， 全浸漬時間が 1 時間となるよう引き続き恒温器で浸漬 · 抽出しだし汁を得た。対照の非照射の試料については, 照射を行わず，同条件下で同時間浸漬・抽出した。だし 汁は，保温による蒸発分は蒸留水を加えて $2 \%(\mathrm{w} / \mathrm{v})$ 溶液になるように調製した後ろ過し，万過液を試料溶液 とした。試料溶液は調製後，直ちに測定を行った。ただ し，高速液体クロマトグラフィー（HPLC）装置を用い た測定項目については，測定まで調製後の試料溶液を $-30^{\circ} \mathrm{C}$ で保存した。

\section{（3）測定方法}

1) $\mathrm{pH}$

$\mathrm{pH}$ は, 各試料溶液 $100 \mathrm{~mL}$ をビーカーに量り取り, $\mathrm{pH}$ メーター（ガラス電極式水素イオン温度指示 F51 ：株式会社堀場製作所）で 1 試料につき 5 回測定した。

\section{2 ) 色 調}

色調の測定は, 試料溶液を角セルに入れ, 浿色色差計 （日本電色株式会社，NE-2000型）により，透過光を測 定し $L, a, b$ 值を得た。 1 試料につき 5 回測定し，そ の平均值と標準偏差を求めた。 $\Delta E$ (色差) の評価は,

N.B.S. 単位 (米国国立標準局が定めた単位)を使用した。

\section{3 ) 全エキス分の定量}

各試料溶液 $10 \mathrm{~mL}$ を秤量ビンに取り，105 $\mathrm{C}^{14)}$ で恒量 に達するまで繰り返し加熱乾燥させ，固形物を全エキス 分とした。なお， 1 試料につき 5 回測定し，二元配置

表 2 だし汁の浸漬時間および超音波処理調製条件

\begin{tabular}{|c|c|c|c|c|c|c|}
\hline 試料 & $\begin{array}{c}\text { 抽出温度 } \\
\left({ }^{\circ} \mathrm{C}\right)\end{array}$ & $\begin{array}{l}\text { 前処理 } \\
\text { (分) }\end{array}$ & $\begin{array}{c}\text { 前浸漬 } \\
\text { 時間 } \\
\text { (分) }\end{array}$ & $\begin{array}{c}\text { 超音波 } \\
\text { 照射時間 } \\
\text { (分) }\end{array}$ & $\begin{array}{c}\text { 照射後の } \\
\text { 浸漬時間 } \\
\text { (分) }\end{array}$ & $\begin{array}{l}\text { 全所要 } \\
\text { 時間 } \\
\text { (分) }\end{array}$ \\
\hline \multirow{3}{*}{$\begin{array}{c}\text { 日本産 } \\
\text { 干しえび }\end{array}$} & 10 & 1 & 30 & $\begin{array}{c}0 \\
10 \\
15 \\
30\end{array}$ & $\begin{array}{c}30 \\
20 \\
15 \\
0\end{array}$ & 60 \\
\hline & 25 & 1 & 30 & $\begin{array}{c}0 \\
10 \\
15 \\
30\end{array}$ & $\begin{array}{c}30 \\
20 \\
15 \\
0\end{array}$ & 60 \\
\hline & 50 & 1 & 30 & $\begin{array}{c}0 \\
10 \\
15 \\
30\end{array}$ & $\begin{array}{c}30 \\
20 \\
15 \\
0\end{array}$ & 60 \\
\hline
\end{tabular}

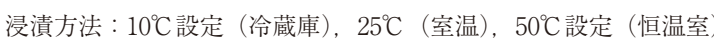


法 ${ }^{15)}$ により分散分析を行った。

\section{4 ）アミノ態窒素の定量}

アミノ態窒素の定量には，ホルモール滴定法を用い

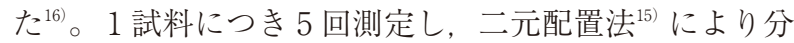
散分析を行った。

\section{5 ） 5 'ーヌクレオチドの定量}

5'ーヌクレオチドの定量は既報 ${ }^{11)} に$ 準じた。 1 試料に つき 5 回測定を行い，二元配置法 ${ }^{15)} に よ り$ 分散分析を 行った。

\section{6 ) 有機酸の定量}

有機酸(乳酸、コハク酸)の定量は既報 ${ }^{17)}$ に準じた。1 試料につき 5 回測定を行い, 二元配置法 ${ }^{15)}$ により分散分 析を行った。

\section{7 ) 遊離アミノ酸の定量}

遊離アミノ酸の定量は, 既報 ${ }^{11)}$ と同様に行いアミノ酸 自動分析計（日立ハイテク L-8500形）で測定した。なお， 1 試料につき 2 回測定を行った。

\section{（4）官能評価}

試料溶液は各干しえびだし汁に食塩0.55\%,ねぎ1.
しょうが $0.5 \%$ の香味野菜を沸騰直後に加え調味した。 1 分間沸騰加熱したものを $70^{\circ} \mathrm{C} に$ 保温し，これを調製た し汁とした。供する直前に $50 \mathrm{~mL}$ ずつ白色食器に分けた。 パネルは，年齢21歳または22歳の若年女性18名で行った。

1 ）順位法

試料溶液は色，こく味，旨味の 3 項目は濃い順，にお い(生臭み)は強い順, 総合評価は好むと感じる順に順位 をつけさせた。検定は，クレーマー検定 ${ }^{18)}$ で解析した。

\section{2 ）２点嗜好試験法変法}

2 種類の試料溶液間の嗜好差の有意性だけでなく，そ の差の程度を推定するため, 2 点嗜好試験法 ${ }^{19)}$ の変法を 用い， 5 項目（色，こく味，旨味，香り，好ましさの項 目における好ましい順位) について 7 段階尺度で評価し， $t$-検定で解析した。

\section{3. 結果および考察}

\section{（1）超音波照射条件の検討}

本実験は，干しえびのだし汁の簡便・迅速で嗜好性の 優れた条件を見出す目的で行った。超音波発振装置の比 較実験を行い, その結果を表 3 ～6に示した。

表 3 干しえびのだし汁の超音波照射時間と抽出温度の相違による $\mathrm{pH}$ 比較

\begin{tabular}{cccccc}
\hline \multirow{2}{*}{ 超音波装置 } & $\begin{array}{c}\text { 抽出温度 } \\
\left({ }^{\circ} \mathrm{C}\right)\end{array}$ & \multicolumn{5}{c}{ 超音波照射時間 (分) } \\
\cline { 2 - 6 } & 10 & $7.80 \pm 0.13$ & $7.92 \pm 0.04$ & $8.01 \pm 0.14$ & $8.06 \pm 0.06$ \\
\hline \multirow{3}{*}{ マルチ周波 } & 25 & $7.80 \pm 0.04$ & $8.05 \pm 0.07$ & $7.84 \pm 0.07$ & $7.95 \pm 0.09$ \\
\cline { 2 - 6 } & 50 & $7.79 \pm 0.06$ & $7.94 \pm 0.02$ & $7.77 \pm 0.05$ & $7.90 \pm 0.08$ \\
\hline & 10 & $7.80 \pm 0.13$ & $7.87 \pm 0.07$ & $7.96 \pm 0.09$ & $7.90 \pm 0.10$ \\
\cline { 2 - 6 } & 25 & $7.80 \pm 0.04$ & $7.93 \pm 0.06$ & $7.76 \pm 0.06$ & $7.81 \pm 0.07$ \\
\cline { 2 - 6 } & 50 & $7.79 \pm 0.06$ & $7.90 \pm 0.05$ & $7.77 \pm 0.07$ & $7.74 \pm 0.07$ \\
\hline
\end{tabular}

平均值士 $(\mathrm{SD})$ であることを記す

表 4 干しえびだし汁の超音波照射時間と抽出温度の相違による色調比較

\begin{tabular}{|c|c|c|c|c|c|c|c|c|c|}
\hline \multirow{2}{*}{$\begin{array}{c}\text { 抽出温度 } \\
\left({ }^{\circ} \mathrm{C}\right)\end{array}$} & \multirow{2}{*}{$\begin{array}{c}\text { 照射時間 } \\
\text { (分) }\end{array}$} & \multicolumn{4}{|c|}{ マルチ周波 } & \multicolumn{4}{|c|}{$200 \mathrm{kHz}$} \\
\hline & & $L$ & $a$ & $b$ & $\begin{array}{c}\Delta E \\
(\text { N.B.S. })\end{array}$ & $L$ & $a$ & $b$ & $\begin{array}{c}\Delta E \\
\text { (N.B.S.) }\end{array}$ \\
\hline \multirow{4}{*}{10} & 0 & 98.78 & -0.13 & 0.68 & 基準 & 98.78 & -0.13 & 0.68 & 基準 \\
\hline & 10 & 94.61 & 0.34 & 3. 11 & 4. 84 & 97.89 & -0.17 & 0.80 & 0.96 \\
\hline & 15 & 95.76 & 0.27 & 2.79 & 3. 70 & 98.52 & -0.07 & 0.83 & 0.31 \\
\hline & 30 & 93.45 & 0.60 & 4. 35 & 6.51 & 98.40 & -0.06 & 0.92 & 0.45 \\
\hline \multirow{4}{*}{25} & 0 & 99.35 & 0.07 & 0.83 & 基準 & 99.35 & 0.07 & 0.83 & 基準 \\
\hline & 10 & 96.79 & 0.38 & 2.43 & 3. 03 & 99.41 & 0.08 & 0.88 & 0.08 \\
\hline & 15 & 96.98 & 0.36 & 2. 47 & 2. 89 & 99.51 & 0.06 & 0.80 & 0.16 \\
\hline & 30 & 95.96 & 0.53 & 3. 14 & 4. 12 & 99.46 & 0.08 & 0.78 & 0.12 \\
\hline \multirow{4}{*}{50} & 0 & 99.43 & 0.09 & 0.88 & 基準 & 99.07 & 0.09 & 0.88 & 基準 \\
\hline & 10 & 96.54 & 0.40 & 2. 75 & 3. 46 & 99.07 & 0.14 & 0.90 & 0.25 \\
\hline & 15 & 97.18 & 0.39 & 2.49 & 2.78 & 99.60 & 0.08 & 0.79 & 0.54 \\
\hline & 30 & 94.78 & 0.69 & 4. 12 & 5.70 & 99.53 & 0.11 & 1. 13 & 0.52 \\
\hline
\end{tabular}

$\triangle E$ : 各抽出温度の非照射を基準とした各照射時間との色差 
1) $\mathrm{pH}$

$\mathrm{pH}$ の変化の結果を表 3 に示した。試料溶液の $\mathrm{pH}$ は 超音波照射の周波数および温度の相違による大差は認め られなかった。照射時間の経過とともに若干 $\mathrm{pH}$ は高く なる傾向がみられた。ほとんどの試料溶液が中性または
弱アルカリ性であった。

\section{2 ) 色 調}

試料溶液の色調の結果を表 4 に示した。色調変化をみ ると，照射の有無に関わらず，いずれの試料溶液も抽出 温度の上昇とともに $L$ 值（明度）は若干低下した。色相

表 5 干しえびだし汁超音波照射時間と抽出温度別の成分比較

\begin{tabular}{|c|c|c|c|c|c|c|c|c|c|c|c|}
\hline \multirow{2}{*}{ 成 分 } & \multirow{2}{*}{ 超音波装置 } & \multirow{2}{*}{$\begin{array}{c}\text { 抽出温度 } \\
\left({ }^{\circ} \mathrm{C}\right)\end{array}$} & \multicolumn{4}{|c|}{ 照射時間（分） } & \multicolumn{2}{|c|}{ 分散比 (F) } & \multicolumn{3}{|c|}{ 寄与率 $(P: \%)$} \\
\hline & & & 0 & 10 & 15 & 30 & 温度 & 時間 & 温度 & 時間 & その他 \\
\hline \multirow{6}{*}{$\begin{array}{l}\text { 全エキス量 } \\
(\mathrm{mg} / 100 \mathrm{~mL})\end{array}$} & \multirow{3}{*}{ マルチ周波 } & 10 & 11.0 & 13.0 & 14.5 & 16.7 & \multirow{3}{*}{$76.40^{* *}$} & \multirow{3}{*}{$51.39^{* *}$} & \multirow{3}{*}{48.2} & \multirow{3}{*}{48.3} & \multirow{3}{*}{3.5} \\
\hline & & 25 & 12.5 & 15.6 & 16.3 & 18. 2 & & & & & \\
\hline & & 50 & 16.1 & 18.3 & 18.6 & 20.1 & & & & & \\
\hline & \multirow{3}{*}{$200 \mathrm{kHz}$} & 10 & 11.0 & 11.3 & 11.4 & 12.3 & \multirow{3}{*}{$395.25^{* *}$} & \multirow{3}{*}{ 4. 41} & \multirow{3}{*}{97.4} & \multirow{3}{*}{1.3} & \multirow{3}{*}{1.4} \\
\hline & & 25 & 12.5 & 12.5 & 12.7 & 13. 0 & & & & & \\
\hline & & 50 & 16.1 & 16.1 & 16.1 & 16.3 & & & & & \\
\hline \multirow{6}{*}{$\begin{array}{l}\text { アミノ態窒素量 } \\
(\mathrm{g} / 100 \mathrm{~mL})\end{array}$} & & 10 & 3.99 & 4.83 & 5.46 & 6.09 & & & & & \\
\hline & マルチ周波 & 25 & 4.98 & 5. 24 & 6.03 & 6.31 & $37.91^{* *}$ & 33. $37^{* *}$ & 40.6 & 53.4 & 6.0 \\
\hline & & 50 & 5.58 & 6.33 & 6.52 & 7.64 & & & & & \\
\hline & & 10 & 3.99 & 4.21 & 4.36 & 4.40 & & & & & \\
\hline & $200 \mathrm{kHz}$ & 25 & 4.98 & 5.00 & 5. 05 & 5.20 & $99.19^{* *}$ & 4. $97^{*}$ & 89.6 & 5.4 & 5.0 \\
\hline & & 50 & 5.58 & 5.62 & 6.18 & 6.37 & & & & & \\
\hline & & 10 & 2.17 & 2.93 & 2.90 & 3.67 & & & & & \\
\hline & マルチ周波 & 25 & 2. 27 & 3. 46 & 3. 49 & 3. 94 & $17.41^{* *}$ & 21.72 & 31.0 & 58.7 & 10.4 \\
\hline 5 '-IMP 量 & & 50 & 3. 00 & 4. 45 & 3. 86 & 4. 22 & & & & & \\
\hline$(\mathrm{mg} / 100 \mathrm{~mL})$ & & 10 & 2.17 & 2.18 & 2.15 & 2.15 & & & & & \\
\hline & $200 \mathrm{kHz}$ & 25 & 2. 27 & 2.65 & 2. 48 & 2. 46 & $98.24^{* *}$ & 1.96 & 93.3 & 1. 4 & 5.3 \\
\hline & & 50 & 3. 00 & 3. 18 & 3. 31 & 3. 31 & & & & & \\
\hline & & 10 & 0.85 & 1. 13 & 1.15 & 1.46 & & & & & \\
\hline & マルチ周波 & 25 & 0.95 & 1.33 & 1.51 & 1. 44 & $25.01^{* *}$ & $21.28^{* *}$ & 40.01 & 50.8 & 9.2 \\
\hline 5'-AMP 量 & & 50 & 1.27 & 1.56 & 1.73 & 1.73 & & & & & \\
\hline$(\mathrm{mg} / 100 \mathrm{~mL})$ & & 10 & 0.85 & 0.91 & 0.85 & 0.83 & & & & & \\
\hline & $200 \mathrm{kHz}$ & 25 & 0.95 & 1. 13 & 1.00 & 1. 02 & $216.27^{* *}$ & $6.88^{*}$ & 93.8 & 3.8 & 2.4 \\
\hline & & 50 & 1.27 & 1.39 & 1.37 & 1.33 & & & & & \\
\hline & & 10 & 0.26 & 0.35 & 0.32 & 0.32 & & & & & \\
\hline & マルチ周波 & 25 & 0.30 & 0.35 & 0.37 & 0.37 & $6.06^{*}$ & $6.06^{*}$ & 27.9 & 41.8 & 30.3 \\
\hline $5^{\prime}-\mathrm{CMP}$ 量 & & 50 & 0.32 & 0.35 & 0.44 & 0.39 & & & & & \\
\hline$(\mathrm{mg} / 100 \mathrm{~mL})$ & & 10 & 0.26 & 0.28 & 0.28 & 0.26 & & & & & \\
\hline & $200 \mathrm{kHz}$ & 25 & 0.30 & 0.31 & 0.33 & 0.30 & 46. $09^{* *}$ & $7.55^{*}$ & 74.6 & 16.3 & 9.1 \\
\hline & & 50 & 0.32 & 0.37 & 0.37 & 0.32 & & & & & \\
\hline & & 10 & 3.60 & 4.71 & 4.78 & 5.20 & & & & & \\
\hline & マルチ周波 & 25 & 3. 99 & 5.12 & 5.54 & 6.07 & $78.66^{* *}$ & $63.55^{* *}$ & 43.9 & 53. 0 & 3. 1 \\
\hline 乳酸量 & & 50 & 5.13 & 5.80 & 6.37 & 6.78 & & & & & \\
\hline$(\mathrm{mg} / 100 \mathrm{~mL})$ & & 10 & 3.60 & 3.65 & 3.91 & 3.68 & & & & & \\
\hline & $200 \mathrm{kHz}$ & 25 & 3. 99 & 4. 02 & 4. 28 & 4.68 & $60.13^{* *}$ & 1.53 & 90.4 & 1.2 & 8.4 \\
\hline & & 50 & 5.13 & 5.12 & 5.24 & 5.11 & & & & & \\
\hline & & 10 & 2.23 & 3.53 & 3.79 & 4.24 & & & & & \\
\hline & マルチ周波 & 25 & 2.94 & 3.90 & 4. 24 & 3.81 & $6.53^{*}$ & $14.80^{* *}$ & 17.4 & 65.2 & 17.3 \\
\hline コハク酸量 & & 50 & 3. 46 & 4. 18 & 4. 38 & 4.58 & & & & & \\
\hline$(\mathrm{mg} / 100 \mathrm{~mL})$ & & 10 & 2. 23 & 2.30 & 2.36 & 2.51 & & & & & \\
\hline & $200 \mathrm{kHz}$ & 25 & 2. 94 & 2.98 & 3. 02 & 3. 20 & $223.9^{* *}$ & 2.9 & 96.4 & 1.2 & 2.4 \\
\hline & & 50 & 3. 46 & 3.53 & 3. 50 & 3. 46 & & & & & \\
\hline$n-5$ & & & & & & & & & & & \\
\hline$p<0.05$ & & & & & & & & & & & \\
\hline$<0.01$ & & & & & & & & & & & \\
\hline
\end{tabular}

$190(6)$ 
では $a$ 值（+は赤味度, 一は緑味度）の変化は少ないが $b$ 值 (+ は黄味度) の変化は大きくなった。マルチ周波 での色の変化は $200 \mathrm{kHz}$ よりも大きかった。マルチ周波 では30分間照射で $a$ 值の赤みが増した。双方とも $b$ 值が 最も大きく変化し, 超音波照射の影響を受けていること が明らかになった。

非照射を基準とした色差では，マルチ周波の色差は非 照射と比べて大きな值となったが，200kHzでは色差は わずかであった。マルチ周波はいずれの抽出温度でも 30 分間照射が4. 12〜6.51 N.B.S. 単位となり, N.B.S. の感 覚的差は「目立つほどにから大いに」の範囲内に評価さ れた。一方, $200 \mathrm{kHz}$ では最小值 0.08 最大值 $0.96 \mathrm{~N}$. B.S. 単位で「かすかに〜わずかに」の範囲内であり, 感覚的な差はほとんどみられなかった。

以上をまとめると, 抽出温度はいずれもマルチ周波が $200 \mathrm{kHz}$ より色調変化が大きく，照射時間はマルチ周波 で30分間の抽出条件がだし汁の着色が最も進み, 非照射 と比べた色差が大きくなることが示された。

\section{3）全エキス分}

全エキス分の結果を表 5 に示した。旨味の指標といわ れる全エキス分は，温度，照射時間を変えたいずれの条 件でも，マルチ周波のほうが多く抽出された。マルチ周 波ではいずれの抽出条件でも，非照射に比べて照射あり の試料で高值を示し, $50^{\circ} \mathrm{C}$ 設定の30分間照射で最大值 $(20.1 \mathrm{mg} / 100 \mathrm{~mL})$ を示した。一方，200kHzでは，抽 出温度の上昇に伴いエキス分は増加したが，照射時間延 長では一定の傾向は認められなかった。

全エキス分の温度による寄与率は，マルチ周波48.2\%, $200 \mathrm{kHz}$ 97.4\%であり，時間による寄与率はマルチ周波 $48.3 \%, 200 \mathrm{kHz} 1.3 \%$ あったことから, 寄与率の要 因はマルチ周波では抽出温度と時間でほほ同じであり, $200 \mathrm{kHz}$ では抽出温度の影響が大きいことが明らかと なった。

\section{4 ）アミノ態窒素量}

アミノ態窒素量の結果を表 5 に示した。マルチ周波で は, いずれの抽出温度条件においても, 非照射に比べて 照射ありの試料溶液はアミノ態窒素量が有意に高值を示 した。照射時間の延長，抽出温度の上昇に伴い值が増加 し，50C，30分照射条件で最大值を示した。いずれの条 件でも，マルチ周波が $200 \mathrm{kHz}$ より多く抽出されており アミノ態窒素の抽出にはマルチ周波が有効であり抽出効 果も大きいことが示された。

アミノ態窒素量の温度による寄与率はマルチ周波 40.6\%, $200 \mathrm{kHz} 89.6 \%$ あ゙り，時間による寄与率はマ ルチ周波では53.4\%，200kHz では5.4\%であった。寄与 率のより大きな要因は，マルチ周波では時間であり，照 射時間延長に伴い, アミノ態窒素は多く抽出されていた。 $200 \mathrm{kHz}$ では抽出温度が照射時間による影響より大き かった。

\section{5 ） 5 ’ーヌクレオチド}

核酸関連物質の 5 -ヌクレオチド (IMP)，アデニル 酸 $(\mathrm{AMP})$ ，シチジル酸（CMP）含量の結果を表 5 に示 した。

測定した 3 成分の中で IMP 含量が高值を示し，特に マルチ周波 $50^{\circ} \mathrm{C}$ ，照射 10 分間が最も抽出量が多かった。 抽出温度の違いで比較すると, 非照射と比較して, $10^{\circ} \mathrm{C}$ 設定， $25^{\circ} \mathrm{C}$ 設定に差はみられなかったが， $50^{\circ} \mathrm{C}$ 設定では 顕著に有意な差がみられた。

マルチ周波では照射時間の変化に伴い，抽出量も大き く変化したが，200kHzでは照射時間に伴う抽出量には 変化がみられなかった。分散比をみるといずれの条件も 抽出温度に有意差が認められた。寄与率ではマルチ周波 はいずれの成分も照射時間の影響を受けており，一方 $200 \mathrm{kHz}$ はいずれの成分も温度による影響を受けている ことが示された。以上の結果から，5’ヌクレオチドの 抽出においてはマルチ周波が $200 \mathrm{kHz}$ と比べて有効であ り, IMP は $50^{\circ} \mathrm{C}$ 設定 10 分間照射, AMP は $50^{\circ} \mathrm{C}$ 設定 15 分 間照射, $\mathrm{CMP}$ は $50^{\circ} \mathrm{C}$ 設定 15 分間照射の各条件で最も効 率よく抽出され，干しえびのだし汁中の呈味成分の多く は IMPであることが示唆された。

\section{6 ) 有機酸}

干しえびのだし汁中の有機酸（乳酸およびコハク酸） 含有量の結果を表 5 に示した。

マルチ周波では，どちらの成分も照射の有無，また抽 出温度の上昇と伴に抽出量が漸増した。また, いずれの 抽出温度でも照射時間が長くなるとともに抽出量が漸増 した。一方 $200 \mathrm{kHz} て ゙ は ，$ 照射時間が長くなっても平衡 状態または減少した。

マルチ周波では，乳酸とコハク酸は照射時間の寄与率 が高く，有意に照射時間の影響を受けていた。 $200 \mathrm{kHz}$ では，照射時間の影響はみられなかった。以上の結果よ り，乳酸・コハク酸の抽出にはマルチ周波が $200 \mathrm{kHz}$ と 比較して有効であり， $50^{\circ} \mathrm{C}$ 設定 30 分間照射が最も抽出さ れることが明示された。マルチ周波使用のだし汁の呈味 成分は，抽出成分の時間依存性が大きく，非照射の試料 に比べて成分量も増加した。 $200 \mathrm{kHz}$ で抽出しただし汁 は温度依存性が大きく，超音波照射時間の影響は認めら れなかった。

\section{7 ）遊離アミノ酸}

干しえびのだし汁中の遊離アミノ酸組成を表 6 に示し た。干しえびだし汁中には旨味・甘味成分のグリシンが 最も多く, 次いで, タウリン，アルギニンが多く含有さ れていた。これまでに述べた測定結果から，マルチ周波 で50드設定，15分間または30分照射が良い条件であるこ とが示唆された。そこで条件を絞り，非照射・非加熱を 含む 6 条件で抽出した。試料の溶液中の遊離アミノ酸組 成を比較した。

苦味成分であるバリン，イソロイシン，チロシン，フェ ニルアラニン含量は，非照射では $25^{\circ} \mathrm{C}$ 設定より $50^{\circ} \mathrm{C}$ 設定 
日本食生活学会誌 Vol.23 No.4（2013）

表 6 干しえびだし汁の超音波照射の有無と抽出条件の相違による遊離アミノ酸組成

\begin{tabular}{|c|c|c|c|c|c|c|}
\hline \multirow{3}{*}{$\begin{array}{c}\text { 遊離アミノ酸 } \\
(\mathrm{mg} / 100 \mathrm{~mL})\end{array}$} & \multirow{3}{*}{$\begin{array}{c}25^{\circ} \mathrm{C} \\
\text { 非照射 } \\
\text { 非加熱 }\end{array}$} & \multicolumn{5}{|c|}{$50^{\circ} \mathrm{C}$} \\
\hline & & \multirow{2}{*}{$\begin{array}{c}\text { 非照射 } \\
\text { 非加熱 }\end{array}$} & \multicolumn{2}{|c|}{ マルチ周波 } & \multicolumn{2}{|c|}{$200 \mathrm{kHz}$} \\
\hline & & & 15分 & 30分 & 15分 & 30分 \\
\hline ホスホセリン & 0.31 & 0.32 & 0.32 & 0.31 & 0.35 & 0.30 \\
\hline タウリン & 4. 00 & 5. 64 & 6.67 & 6.56 & 6. 48 & 5.79 \\
\hline ホスホエタノールアミン & 0.12 & 0.00 & 0.00 & 0.00 & 0.00 & 0.00 \\
\hline トレオニン & 0.47 & 0.85 & 0.89 & 0.90 & 0.60 & 0.65 \\
\hline セリン & 0.66 & 1. 12 & 1. 27 & 1.08 & 0.77 & 0.82 \\
\hline アスパラギン & 0.44 & 0.73 & 0.78 & 0.84 & 0.59 & 0.63 \\
\hline グルタミン酸 & 0.66 & 1.00 & 0.99 & 1. 23 & 0.88 & 0.93 \\
\hline グルタミン & 0.53 & 0.85 & 0.98 & 1. 22 & 0.61 & 0.79 \\
\hline 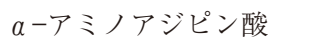 & 0.00 & 0.00 & 0.00 & 0.00 & 0.00 & 0.00 \\
\hline グリシン & 10.59 & 15. 34 & 16.40 & 18.80 & 13. 41 & 14.34 \\
\hline アラニン & 1.63 & 2.61 & 2.79 & 3. 08 & 2.20 & 2. 60 \\
\hline バリン & 1.36 & 1.82 & 1.70 & 1.83 & 1. 63 & 1.59 \\
\hline メチオニン & 0.95 & 1.06 & 1. 14 & 1. 23 & 1. 12 & 1. 03 \\
\hline シスタチオニン & 0.72 & 0.83 & 0.82 & 0.67 & 0.76 & 0.73 \\
\hline イソロイシン & 0.81 & 1. 01 & 1.07 & 1. 12 & 0.97 & 0.89 \\
\hline ロイシン & 1. 13 & 1.58 & 1. 54 & 1.82 & 1.33 & 1. 26 \\
\hline チロシン & 1.32 & 1.58 & 1.71 & 1.65 & 1. 64 & 1. 31 \\
\hline フェニルアラニン & 1.04 & 1. 17 & 1. 16 & 1. 10 & 1.08 & 0.92 \\
\hline$\beta$-アラニン & 0.00 & 0.00 & 0.89 & 0.00 & 0.00 & 0.00 \\
\hline アンモニア & 0.78 & 0.68 & 0.59 & 0.74 & 0.74 & 0.64 \\
\hline オルニチン & 0.00 & 0.00 & 0.00 & 0.00 & 0.00 & 0.00 \\
\hline リジン & 0.89 & 1.05 & 1. 28 & 1.32 & 0.92 & 0.95 \\
\hline ヒスチジン & 0.19 & 0.36 & 0.51 & 0.54 & 0.00 & 0.00 \\
\hline カルシノン & 3.73 & 0.00 & 0.00 & 0.00 & 0.00 & 0.00 \\
\hline アルギニン & 7.27 & 11.11 & 12.93 & 15.51 & 9.59 & 12.28 \\
\hline プロリン & 2.01 & 2.93 & 3.20 & 3.41 & 2.81 & 2.93 \\
\hline 総 量 & 41.60 & 53.63 & 59.66 & 64.93 & 47.95 & 49.79 \\
\hline
\end{tabular}

のほうが多く抽出されていた。さらに $50^{\circ} \mathrm{C}$ 設定で比較す ると $200 \mathrm{kHz}$ では非照射より，大部分のアミノ酸が減少 した。遊離アミノ酸総量をみるとマルチ周波で $50^{\circ} \mathrm{C}$ 設定, 30分照射が最も多く抽出した。

以上の結果より，遊離アミノ酸抽出にはマルチ周波の 有効活用が期待できることが示唆された。

\section{（2）官能評価}

\section{1) 順位法}

干しえびのだし汁の好適調製条件を検討するため順位 法による官能評価を行った。これまでの測定結果から良 いとされたマルチ周波で抽出温度 $25^{\circ} \mathrm{C}$ 設定と $50^{\circ} \mathrm{C}$ 設定の 条件で抽出した干しえびだし汁を用いて，一定条件で調
味した調製だし汁について, クレーマーの順位法による 官能評価を行い, 総合的評価 (色・こく味・旨味・香り・ 総合評価）を行った。その結果を表 7 に示す。

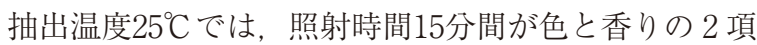
目に扔いて有意に評価が高く，総合的評価でも好ましい

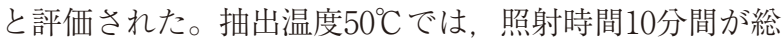
合的に好まれた。一方, 非照射の試料ではすべての項目 で有意に好まれず，超音波照射の有効性が確認できた。

\section{2)２点嗜好試験法の変法}

順位法で好ましいと評価された 2 試料を 2 点嗜好試験 法の変法で比較した結果を図 1 に示した。マルチ周波の 場合, 抽出温度 $50^{\circ} \mathrm{C}$ 設定で照射 10 分間は, 基本の抽出温 度 $25^{\circ} \mathrm{C}$ 設定で照射 15 分間と比べて，色，こく味，旨味の 
表 7 干しえびだし汁の官能評価

\begin{tabular}{|c|c|c|c|c|c|c|c|c|c|c|c|}
\hline \multirow{3}{*}{$\begin{array}{c}\text { 超音波 } \\
\text { 装置 }\end{array}$} & \multirow{3}{*}{$\begin{array}{c}\text { 照射時間 } \\
\text { (分) }\end{array}$} & \multicolumn{10}{|c|}{ 抽出温度 $\left({ }^{\circ} \mathrm{C}\right)$} \\
\hline & & \multicolumn{5}{|c|}{25} & \multicolumn{5}{|c|}{50} \\
\hline & & 色 & こく味 & 旨味 & におい & $\begin{array}{l}\text { 総合 } \\
\text { 評価 }\end{array}$ & 色 & こく味 & 旨味 & におい & $\begin{array}{l}\text { 総合 } \\
\text { 評価 }\end{array}$ \\
\hline \multirow{4}{*}{ マルチ周波 } & 0 & $72^{* *}$ & $63^{* *}$ & $61^{* *}$ & $61^{* *}$ & $65^{* *}$ & $71^{* *}$ & $66^{* *}$ & $65^{* *}$ & $59^{* *}$ & $63^{* *}$ \\
\hline & 10 & 53 & 43 & 40 & 44 & 36 & 48 & 36 & 34 & 46 & $29^{* *}$ \\
\hline & 15 & $28^{* *}$ & 36 & 36 & $32^{*}$ & $33^{*}$ & $32^{*}$ & 46 & 45 & 42 & 41 \\
\hline & 30 & $27^{* *}$ & 38 & 43 & 43 & 46 & $29^{* *}$ & $32^{*}$ & 36 & $33^{*}$ & 47 \\
\hline \multicolumn{12}{|c|}{$\begin{aligned} \text { 順位法 } \quad & n=18 \\
& * p<0.05 \\
& *{ }^{* *} p<0.01\end{aligned}$} \\
\hline
\end{tabular}

\begin{abstract}
$\mathrm{A}:$ 抽出温度 $50^{\circ} \mathrm{C}$, マルチ周波10分間 基本：抽出温度 $25^{\circ} \mathrm{C}$, マルチ周波15分間
\end{abstract}

A

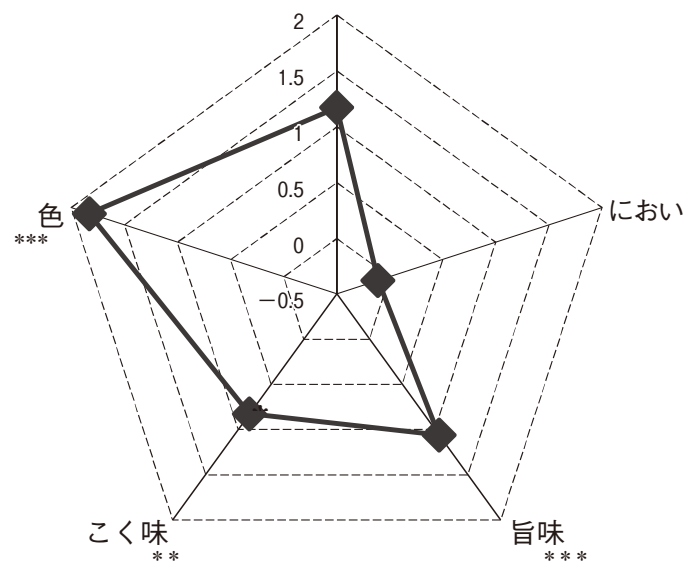

B : 抽出温度 $50^{\circ} \mathrm{C}$, マルチ周波 10 分間

基本：抽出温度 $50^{\circ} \mathrm{C}$, 非照射

B

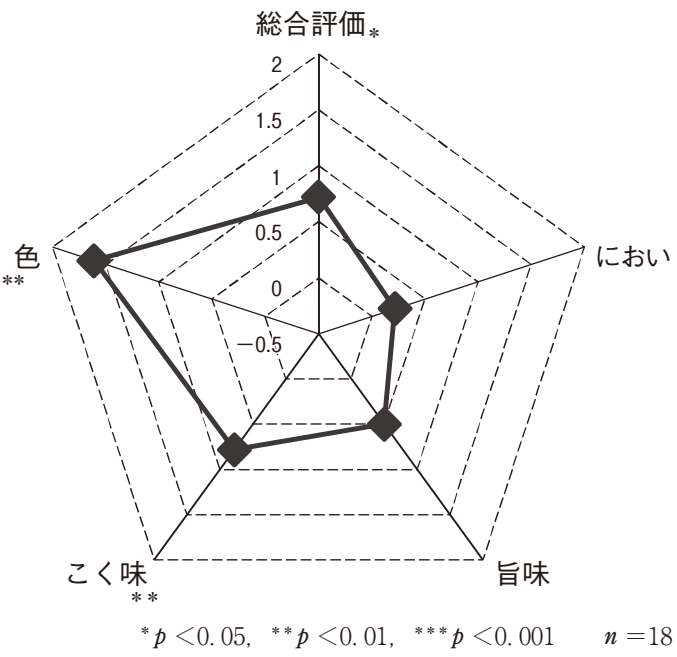

図 1 二点嗜好試験法変法での官能評価

3 項目と総合評価で有意に好ましいと評価された。この 官能評価の結果とこれまでの分析結果において，マルチ 周波では，抽出温度は $50^{\circ} \mathrm{C}$ 設定が $25^{\circ} \mathrm{C}$ 設定より高值が得 られたことと一致した。さらに，抽出温度 $50^{\circ} \mathrm{C}$ 設定で, 照射10分間の有無を比較したところ，基本の照射なしと 比べて照射したほうがすべての項目において，評価が高 く，有意に好ましいと評価された。

以上の結果から，干しえびのだし汁の最適抽出条件は マルチ周波で抽出温度 $50^{\circ} \mathrm{C}$ 設定，照射時間 10 分間である ことが客観的評価として確認できた。

\section{4. まとめ}

日本産干しえびのだし汁の迅速かつ合理的な抽出法に より嗜好性に優れた条件を見出す目的で，従来の一時間 浸水法の過程に超音波照射を併用し，周波数と照射時間 の相違による抽出効果のモデル実験を試みた。だし汁中 の呈味成分，色調と嗜好の関係を明らかにするとともに
干しえびのだし汁の好適な調製条件について検討した。

1 ) 超音波照射した試料は非照射に比べ, $L *$ はやや低く, $b$ 值は大きくなった。マルチ周波は $200 \mathrm{kHz}$ より, $a$ 值, $b$ 值， $\Delta E$ が高值を示した。

2）全エキス，アミノ態窒素量, IMP, AMP, 乳酸は, マルチ周波, $200 \mathrm{kHz}$ ともに, 温度上昇に伴い増加し た $(p<0.01)$ 。IMP はマルチ周波 10 分間照射の $50^{\circ} \mathrm{C}$ 設定, 遊離アミノ酸はマルチ周波 30 分間照射の $50^{\circ} \mathrm{C}$ 設 定が最高值を示した。

3 ）順位法による官能評価では, 抽出温度 $25^{\circ} \mathrm{C}$ 設定はマ ルチ周波15分間照射， $50^{\circ} \mathrm{C}$ 設定ではマルチ周波10分間 照射が有意に好まれた $(p<0.01)$ 。さらに 2 点嗜好 試験法変法でこれらの 2 試料を比較すると，抽出温度 $50^{\circ} \mathrm{C}$ のマルチ周波10分間照射が色，こく味，旨味，総 合的好ましさで有意に高い評価が得られた（ $p<$ 0. 001)。

以上の結果から，干しえびのだし汁の好適調製条件は 
旨味成分であるアミノ態窒素, IMP の含有量や官能評 価から判断すると，周波数の小さいマルチ周波の超音波 照射の併用は非照射よりも，呈味成分の抽出も多く，特 に抽出温度 $50^{\circ} \mathrm{C}$ 設定のマルチ周波 10 分間照射は有効で あった。また成分抽出值は, 低周波の方が中周波より, キャビテーション, 振動加速度, 直進流の物理的作用の 影響が大きいことが明らかとなった。

\section{謝辞}

最後に，本研究中に急逝された元椙山女学園大学教授 木村友子博士のご冥福を扮祈り申し上げます。また，長 年にわたり，優しさと情熱にあふれたご指導を賜りまし たことに，深謝の意を表します。

\section{文献}

1）菅原龍幸，井上四郎編集：新版原色食品図鑑，建帛社, 東京, p.94-96（1991）

2 ）武恒子, 本田良二, 大塚一止：各種食品中の呈味成分に 関する研究（第 2 報）えびの呈味成分について，栄養と食糧， 17. 268-274 (1964)

3 ) M. Matsumoto, and H. Yamanaka: Post-mortem Biochemical Changes in the Muscle of Kuruma Prawn during Storage and Evaluation of the Freshness, Nippon Suisan Gakkaishi, 56 ( 7 ), 1145-1149 (1990)

4 ）松本美鈴, 山中英明：クルマエビの死後硬直に関する研究, 日本水産学会誌，57（1），2121-2126（1991）

5 ）松本美鈴，山中英明，畑江敬子：クルマエビ筋肉の生化 学的変化に及ぼすあらい処理の影響, 日本水産学会誌, 57 (7), 1383-1387 (1991)

6 ）鴻巣章二：エビ類の呈味成分, 海洋科学, 12, 839-849(1980)
7 ）藤田真夫，遠藤金次，清水亘：水産動物肉に関する研究 46, えび類の筋肉エキス中の遊離アミノ酸, トリメチルア ミン・オキサイドおよびベタインについて, 近畿大農学部 紀要，5，61-65（1972）

8 ）藤田真夫，遠藤金次，清水亘：水産動物肉に関する研究 47, クルマエビの筋肉中のエキス窒素成分の季節的変化, 近畿大農学部紀要, 5, 66-73 (1972)

9 ）安部テル子, 佐藤美由, 工藤香織, 山内愛津子, 水江智子 : えびスープの成分および味に及ぼす頭胸部と殼の影響, 日 本家政学会誌，52（6），491-497（2001）

10）木村友子，菅原龍幸，福谷洋子，加賀谷みえ子：超音波 照射が干し椎茸の水戻しに及ぼす影響, 日本家政学会誌, $45(7), 585-593(1994)$

11）木村友子, 菅原龍幸, 福谷洋子, 佐々木弘子：昆布だし 汁の浸水法に及ぼす超音波照射の影響, 日本家政学雑誌, 47 ( 5 ), 453-460 (1995)

12）木村友子, 菅原龍幸, 福谷洋子, 佐々木弘子：昆布だし の加熱抽出法における超音波照射の効果, 日本調理科学会誌, 29 ( 3 ) , 178-185 (1996)

13）木村友子, 菅原龍幸, 福谷洋子，佐々木弘子：䳕骨ス一 プストック調整法に抢ける超音波照射の効果，日本家政学 会誌，48（2），153-160（1997）

14）飯盛和代：改訂食品学実験ノート, 建帛社, 東京, p.5253 (1998)

15）田口玄一：第 3 実験計画法(上), 丸善, 東京, p. 1 -18(1983)

16）菅原龍幸：食品学実験書, 建帛社, 東京, p.100-101 (1995)

17）佐々木弘子，武田槙子，藤原しのぶ，伊藤輝子：市販食 酢の成分，聖徳大学研究紀要，人文学部，17，87-92（2006）

18）大越ひろ，神宮英夫編著：食の官能評価入門，光生館, 東京, p.43-67 (2009)

19）佐藤信：統計的官能調査法，日科技連出版社，東京，p.3756 (1985) 